\title{
An Approach to Monetary and Fiscal Management
}

\author{
A speech given by DARRYL R. FRANCIS, President, Federal Reserve \\ Bank of St. Louis, before The Money Marketeers, New York City \\ October 30, 1968.
}

\begin{abstract}
ANYONE who is seriously interested in economic stabilization policy may be very much in a quandary at the present time. There is general acceptance of the goals of stabilization policy which include high employment, rising output, and relatively stable prices. However, there is much debate regarding methods and procedures for achieving these goals.
\end{abstract}

A case in point is the fiscal package adopted this past summer. There was widespread belief at the time of its adoption that the surtax and the curbs on Government expenditures provided a massive dose of fiscal restraint. Some believed that this action offered an immediate and strong restraint on the rate of increase in total spending, leading thereby to a reduc tion in inflationary pressures. In fact, some analysts argued that there was need for relaxation of monetary restraint, such as there was, to avoid a recession in late 1968 or early 1969.

Such consequences of last summer's action have not as yet materialized. Gross national product rose at an excessive 9 per cent rate from the second to the third quarter, only a little less than the inflationary 11 per cent rate of increase from the first to the second quarter. The over-all price index rose at about a 4 per cent rate in the third quarter, continuing the trend of the past year and a half. These unexpected developments have produced considerable concem among monetary and fiscal authorities, as well as among interested segments of the public in general. Questions are now being raised about the validity of some generally accepted propositions underlying monetary and fiscal management.

Tonight I will discuss an approach to monetary and fiscal management which 1 believe may provide a basis for more rational economic stabilization policy. I will identify this approach as the "Monetary View." It is my opinion that the usual division of fiscal and monetary actions into separate entities with differing relative importance has frequently led to inappropriate and unexpected developments. Price stability and high employment achievements have often been less satisfactory than would have been practical.

Before moving on to the main body of my remarks, I want to clarify briefly my use of the term "Monetary View." Most economists today believe that monetary actions have an important role in economic stabilization, but there is lack of agreement on what constitutes such actions or their relative importance. Many economists stress the influence of monetary authorities in terms of market interest rates. Others measure this influence in terms of member bank reserves, the monetary base, the money stock, or similar aggregates. Still others consider changes in various measures of credit to be important. The view I discuss tonight holds that for economic stabilization purposes monetary actions are best measured by changes in the money stock and that such changes are a major factor determining total spending, that is, gross national product.

I will develop this view in a sequence of three topics: first, some basic premises underlying this approach to economic stabilization; second, some specific principles regarding monetary management which follow from these premises; finally, an appraisal of the current economic situation in terms of these principles.

\section{Four Basic Premises}

In discussing a proposed approach to monetary and fiscal management, one must set forth at an early stage its basic premises. Failure to do so often leads to misunderstandings. Of course, there is a hazard explicit assertion of underlying premises may lead to challenge and possible doubt being cast on the recommended course of action. Yet, the desire to improve monetary and fiscal management necessarily involves a willingness to subject all recommendations to close examination by others. Development of proper procedures for economic stabilization will evolve only through a process of offering propositions which may be subjected to repeated examination and testing.

Accordingly, I advance the following four premises underlying my version of the Monetary View. First, a predominantly market orientation is most appropriate for monetary and fiscal analysis. Second, quantification is essential if economic stabilization is to become more of a science than a guessing game. Third, our economic system is more stable than was believed a few years ago. Fourth, monetary management is more properly directed toward influencing changes in total spending than toward concern for its 
impact on selected markets. Let us now examine each in more detail.

\section{Premise One: Market Orientation}

Market orientation holds a foremost position in current economic thinking. A basic principle of economics is that free markets are the most efficient allocator of both real and financial assets. Free interplay of market forces results in an efficient allocation of scarce resources and in production directed by the public's preferences.

Contemporary theories of monetary and fiscal management, as distinguished from traditional Keynesian economics stemming from the 1930 's, stress the role of individual markets. These current theories have gained growing emphasis since the early 1950 's. They are based on an examination of the factors determining consumers' or businessmen's choices among a wide variety of real and financial assets. Decisions of these and other economic units are studied as they are manifested through the operations of markets. At a fundamental level there is little basic difference between the "portfolio" extension of traditional Keynesian economics and the "broader portfolio" approach to economic theory sometimes called the "Modern Quantity Theory." Some noted economists identified with the modified Keynesian or "portfolio" view are James Tobin, Paul Samuelson, and James Duesenberry. Leading advocates of the Modem Quantity Theory include Karl Brunner, Allan Meltzer, and Milton Friedman. Despite some differences, both views are market-oriented.

\section{Premise Two: Quantifcation is Essental}

Quantification of both actions and results is required for development and implementation of rational procedures for stabilization policy. Those responsible for carrying out stabilization responsibilities require considerable knowledge of the probable results of any particular course of action. Such knowledge includes identification of strategic variables and specification of operational hypotheses about the end results expected from altemative courses of action. Development of this knowledge requires empirical verification of various economic theories.

Not only the results, but also the actions, must be measurable. Rational economic stabilization policy requires that its operations be conducted in terms of specified and measurable changes in strategic variables. Vague concepts such as "easier," "tighter," or "more restrictive" carry little operational content for monetary management. If the FOMC directive contained truly quantified instructions, those responsible for its implementation would receive definite rather than impressionistic instructions. Under these conditions monetary managers at all levels could be held accountable for the success or failure of their actions.

This ideal of quantification is not out of reach. Since World War II much research has pointed to the possibility of improving the precision of economic stabilization. Statistical analyses and econometric procedures have been applied to a wide variety of economic problems. Quantitative methods for making decisions in the face of uncertainty have been successfully applied to many problems of business management. It is time that scientific methodology and modern quantitative analysis be used to a greater extent in developing appropriate procedures for monetary and fiscal management.

\section{Premise Thee: Wheren Economic Stability}

The proposition of inherent economic stability is beginning to play a more important role in thinking about economic stabilization policy. Until recently there was quite general acceptance of the view that there is basic instability in the economy which produces wide fluctuations in output and employment. Some recent studies have cast considerable doubt upon this view. In its place is proposed the proposition that there is a high degree of inherent stability in our economic system. According to this proposition, population, natural resources, capital formation, and technology determine growth in output of goods and services. Since these factors change slowly and exert a powerful influence, they provide great underlying stability to the trend growth of output and employ. ment. Variations in total spending can be induced by monetary and fiscal actions, but they have only a short-run effect on output and employment. In the longer run they mainly affect the price level.

\section{Premise Four: Focws on rotal Spending}

This proposition is based on the generally accepted proposition that economic stabilization actions should be concerned primarily with prevention of inflation or deflation. Such price movements are viewed as detrimental to the well-being of our citizens. At times actions are required to match growth in total spending to growth permitted by increases in our economy's productive potential. Such actions may be viewed by some as impinging unduly on certain sectors of our economy. But when free markets are allowed to channel the influence of monetary and fiscal actions throughout the multitude of individual markets for goods, services, and financial assets, over-all economic efficiency and individual freedom will be less af- 
fected. Of course, many markets do not meet completely the criterion of "free"; but, nevertheless, the allocation of resources through imperfect markets is to be preferred over allocations made by administrative fiat. Furthermore, markets could be made more free if various price and interest rate controls were relaxed.

\section{Propositions for Monetary and Fiscal Management}

Application of these four basic premises leads to a number of specific propositions regarding the conduct of monetary and fiscal management. Let me now discuss these propositions as they apply to the monetary aspects of economic stabilization policy.

Monetary management is properly directed, in the main, toward infuencing movements in total spending for goods and services. Such movements should be consistent with price level and employment goals and with fulfillment of our economy's productive potential. Incidentally, the inherent stability I mentioned previously still leaves room for discretionary monetary management. Monetary forces must be managed if they themselves are not to be a source of economic instability. Also, the impact of Government deficits and surpluses on total spending depends greatly on the extent to which monetary authorities monetize changes in the national debt.

Recent theoretical and empirical research has raised doubts regarding the validity of some widely held concepts of monetary management. The use of such vague concepts as "tone" and "feel" of the money market have been found to carry little useful information. Measures of money market conditions such as market interest rates and free reserves have been shown to be poor indicators of the influence of monetary actions. These two measures are affected greatly by forces other than actions of monetary authorities; hence, interpretation of their movements for economic stabilization purposes is problematic. Likewise, "tight money," as measured by money market indicators (in other words, high interest rates), does not necessarily indicate restrictive monetary actions in terms of their influence on growth in total spending. Instead, high or rising interest rates are frequently the result of excessive monetary stimulus in the past rather than of present restraint.

Primary and consistent use of monetary aggregates, a practice which has not prevailed heretofore, would seem to be essential for sound monetary policy. Certain aggregates such as Federal Reserve credit, member bank reserves, the monetary base, and the money stock have been shown on theoretical and empirical grounds to be useful and important tools of monetary management. All of these aggregates can be rather precisely controlled by monetary authorities. Much of contemporary monetary theory and related research has assigned an important role in economic stabilization to some of these or closely related measures. In many recent studies changes in the outstanding volume of these aggregates are viewed as influencing total spending through changes in market-determined prices and interest rates. But I want to point out that it is changes in monetary aggregates which initiate changes in total spending; interest rates and prices only constitute the transmission mechanism. For stabilization purposes, movements in interest rates should be viewed no differently than movements in commodity prices.

The monetary view I am espousing includes the following points. Changes in Federal Reserve credit are under direct Federal Reserve control and have been found to be the main determinant of the monetary base. Since the monetary base is subject to rather precise Federal Reserve control, it is a very useful indicator of Federal Reserve actions. This statement holds regardless of what indicator is used by the Federal Reserve, because the result of System actions is reflected in the monetary base. A very stable empirical relationship has been found to exist between the monetary base and the money stock. Consequently, the money stock is viewed as a good measure of over-all monetary influence. It reflects primary actions of the Federal Reserve System, taking account of decisions of others involved in the monetary process, specifically, commercial banks, the nonbank public, and the Treasury.

This brings me to the most important aspect of my suggested approach to economic stabilization the proposition that monetary actions are a major determinant of short-run movements in total spending. This is in contrast with much of the current economic stabilization theory and practice. It has been fashionable to ascribe to fiscal actions a large and immediate effect on total spending and to monetary actions a small and long-delayed effect. Consequently, taxing and Government spending actions have been assigned the major role in economic stabilization. Monetary actions, according to some proponents of this dominant view, are of small consequence, with little effect on total spending, output, and prices. These same proponents argue, however, that monetary actions have a potential for doing great harm to specific sectors of the economy, for example, thrift institutions and the housing industry. They conclude that actions of monetary authorities are more properly directed toward the well-being of these sectors than toward influencing total spending. 
Much research has recently been devoted to testing the proposition that monetary actions are a major determinant of total spending, but the issue is far from settled. Friedman in the early 1950's advanced on empirical and theoretical grounds the proposition that money is the most important determinant of economic activity. In extensive tests conducted a few years ago in collaboration with David Meiselman, he concluded that money rather than autonomous expenditures, which include fiscal actions, is the major determinant of consumption expenditures. This proposition was immediately challenged by several economists. Franco Modigliani and Albert Ando, major figures in this debate, reported tests which showed that money was an important, but not the most important, determinant of consumption spending.

Thomas Mayer, one of the original challengers of the Friedman position, concluded in a recent book that much recent evidence supports the view that the money stock, and therefore monetary policy, has a substantial effect on income. He points out, however, that there is not general acceptance of the view that the money stock has a dominant effect.

All this research did not test directly the relative importance of monetary and fiscal actions in economic stabilization. At the Federal Reserve Bank of St. Louis we have recently made an attempt to test their relative importance. I summarize the results of this research as an example of one attempt to provide a more scientific underpinning to stabilization policies.

The time period examined was from 1947 to mid1968. Monetary actions, measured by changes in the narrowly defined money stock, accounted for about 40 per cent of the variation of quarter-to-quarter changes in GNP. Changes in tax rates were found to have little, if any, direct influence on changes in GNP. Changes in Government expenditures explained a comparatively small per cent of changes in GNP. This evidence does not support the conven tional view that fiscal actions evoke a larger and faster response in total spending than do monetary actions.

The influence of monetary actions on GNP is quite large in the quarter in which they occur, larger yet in the next quarter, and is fully manifested by two quarters after action is taken. The infuence of changes in Government spending, on the other hand

\footnotetext{
"An article based on the research referred to in this speech is also published in this issue of the Review. The article, "Monetary and Fiscal Actions: A Test of Their Relative Importance In Economic Stabilization" by Leonall C. Andersen and Jerry L. Jordan, reports results for a somewhat different time period than discussed in this speech. The results reported in the article strengthen and expand the conclusions discussed here.
}

is relatively small, and its impact is not fully manifested until three quarters after a change. Once again, the conventional view is not supported.

These results suggest that the following hypotheses for economic stabilization are more appropriate than the conventional ones used at the present time. The response of total spending to changes in the money stock is relatively large and fast. By contrast, the response to changes in Government taxing provisions is negligible. Furthermore, the response of total spending to changes in Government expenditure programs is much smaller than its response to changes in money, and the ultimate effect takes a longer time interval.

An additional point raised is that the manner of financing Government expenditures provides the main avenue by which fiscal actions influence total spending. Financing expenditures by borrowing from the public is not much different in its impact on total spending from taxing. Government expenditures financed by monetary expansion, however, will be expansionary. Most studies, until recently, using traditional Keynesian analysis ignore this consideration.

Another result of our research on the determinants of total spending is that forces other than monetary and fiscal actions exert a significant influence, but that this influence is less than that of money. These other forces have not been examined in detail, but it is believed that they include changes in consumer and investor preferences, outbreak of war, and strikes in major industries. There is considerable doubt in my mind whether any stabilization actions could provide effective offsets to such forces as these.

The hypotheses advanced by this research should, of course, be subjected to repeated testing. As I said earlier, only by advancing propositions, testing them, and having them challenged by others will progress be made toward developing rational procedures for economic stabilization.

Finally, the evidence pointing to the strength and speed of the influence of monetary actions on total spending leads to the conclusion that attempts by monetary authorities to control developments in specific markets are undesirable on both allocation and stabilization grounds. Regulation of interest rates paid by commercial banks and thrift institutions unduly disrupts the allocation function of markets. Furthermore, excessive concern for the well-being of these institutions and the housing industry has caused monetary authorities to expand the money stock at a rapid rate during much of the current inflationary period. 
Undue concern for the well-being of the Government securities market and the concept of "even keel" during Treasury financing are other impediments to rational monetary management. These considerations have greatly hampered the carrying out of monetary actions designed to influence or to maintain an appropriate rate of expansion in total spending. For example, during the last nine months of 1967 the FOMC imposed the even-keel constraint more than half the time. In those periods the money stock grew at a 12 per cent rate during Treasury financings and at a 4 per cent rate the remainder of the periods. The result was an overall increase in money at a 7 per cent rate, an excessive rate of increase in view of the mounting inflationary pressures.

In summary, the monetary approach to economic stabilization I have just presented incorporates the following points:

(1) Public stabilization policies should focus on total spending, allowing markets to filter their influence throughout the economy.

(2) Monetary actions are a very important influence on changes in total spending.

(3) The money stock is the best measure of the influence of monetary actions on total spending, given the current state of knowledge.

(4) Growth in total spending at a rate consistent with price level and employment objectives is more important to the over-all well-being of our citizens than are monetary actions directed toward the welfare of special sectors.

\section{Monetary Interpretation of the Current Economic Situation}

I now turn to a monetary interpretation of recent economic developments. As a result of the fiscal actions of last June, it is estimated that the high-employment budget will swing from a $\$ 16$ billion deficit (annual rate) in the second quarter of 1968 to a $\$ 15$ billion rate of surplus a year later. This $\$ 31$ billion turnaround within a year has been cited as a massive dose of fiscal restraint. The money stock continued to rise rapidly up to mid-summer followed by a more moderate rate of growth in the last three months.

For purposes of this analysis, I will use the propositions advanced by the study I reported earlier. It concluded that the response of total spending to monetary actions is much larger than the response to fiscal actions and that the monetary response occurs within a shorter time period. Applying this proposition, little slowdown in GNP growth should have been expected in the recent third quarter. GNP was under the influence of rapid monetary expansion in the previous two quarters. One factor tending to offset partially the influence of the rapid monetary expansion to July on GNP was the rundown in steel inventories built up in expectation of a steel strike. This factor, however, was not related to stabilization actions.

What does the results of this research imply for the influence of the fiscal package? The impact would come from sources other than those cited last summer. The increase in tax rates by itself, according to our study, would have virtually no influence on total spending, and a reduced rate of increase in Government spending, if implemented, would have only a small direct effect. The main restraining infuence of the fiscal package would result from the Government having to finance a smaller deficit, thereby relieving upward pressures on interest rates. Attempts to offset such pressures in the past have induced excessively rapid monetary expansion during inffationary periods.

Growth of GNP during the next three quarters, according to this monetary view, as supplemented by our research, depends largely on the rate of increase in the money stock. If money should rise rapidly, there will be little reduction in the rate of expansion in total spending. Only if the recent slower rate of monetary expansion is continued will there be appropriately slower growth in total spending and a reduction in inflationary pressures.

\section{Conclusion}

In conclusion, I want to point out two important implications of this monetary view for the conduct of economic stabilization policies. First, the proposition that monetary actions, measured by movements in the money stock, have a large and immediate effect on total spending implies that the monetary authorities should not engage in activities which cause large swings in growth of money. Second, the proposition that the infuence of fiscal actions is comparatively small and longer delayed implies that if we are to have appropriate results from stabilization policies, monetary authorities should not wait for fiscal measures to be undertaken before changing the thrust of their own actions.

This article is available as reprint series No. 33 . 